\title{
Virulence and genotypic characterization of Listeria monocytogenes isolated from vegetable and soil samples
}

\author{
Dharmendra Kumar Soni ${ }^{1}$, Major Singh ${ }^{2}$, Durg Vijai Singh ${ }^{3}$ and Suresh Kumar Dubey ${ }^{1 *}$
}

\begin{abstract}
Background: Listeria monocytogenes, a foodborne pathogen is ubiquitous to different environments including the agroecosystem. The organism poses serious public health problem. Therefore, an attempt has been made to gain further insight to their antibiotic susceptibility, serotypes and the virulence genes.

Results: Out of the 10 vegetables selected, 6 (brinjal, cauliflower, dolichos-bean, tomato, chappan-kaddu and chilli), 20 isolates (10\%) tested positive for L. monocytogenes. The prevalence of the pathogen in the respective rhizosphere soil samples was $5 \%$. Noticeably, L. monocytogenes was absent from only cabbage, broccoli, palak and cowpea, and also the respective rhizospheric soils. The 30 isolates + ve for pathogenicity, belonged to serogroup 4b, 4d or 4e, and all were positive for in/A, in/C, inlJ, plcA, prfA, actA, hlyA and iap gene except one (VC3) among the vegetable isolates that lacked the plCA gene. ERIC- and REP-PCR collectively revealed that isolates from vegetables and their respective rhizospheric soils had distinct PCR fingerprints.

Conclusions: The study demonstrates the prevalence of pathogenic L. monocytogenes in the selected agricultural farm samples. The increase in the number of strains resistant to ciprofloxacin and/or cefoxitin seems to pose serious public health consequences.
\end{abstract}

Keywords: Serotype identification, ERIC- and REP-PCR, Virulence genes, Multiplex PCR

\section{Background}

Listeria monocytogenes, the foodborne pathogen, causes listeriosis with high mortality rates $(\sim 30 \%)$, and presently considered to pose serious public health problem [1]. The organism survives diverse conditions such as low temperature, low $\mathrm{pH}$ and high salt concentrations, and manifests abortion, stillbirth, septicemia, meningitis and meningoencephalitis in pregnant women, neonates, elderly, or immune-compromised humans [2,3]. Usually, $L$. monocytogenes is susceptible to a wide range of antibiotics, but resistance to multiple antibiotics is also on record $[4,5]$. The presence of a number of virulence factors such as internalins (encoded by $i n l A$, inlC, inl)), listeriolysin $\mathrm{O}$ (LLO encoded by $h l y A$ ), actin (actA), phosphatidylinositol-phospholipase C (PI-PLC encoded by $p l c A$ ), iap (invasion associated protein encoded by iap) and virulence

\footnotetext{
* Correspondence: skdubey@bhu.ac.in

'Department of Botany, Banaras Hindu University, Varanasi 221005, India Full list of author information is available at the end of the article
}

regulator (encoded by prfA), in L. monocytogenes significantly regulates the pathogenicity [6,7]. Serotyping of $L$. monocytogenes from different sources revealed difference in their virulence attribute [8-10]. The isolates from food and environmental samples belonged to a small number of serotypes $1 / 2 \mathrm{a}, 1 / 2 \mathrm{~b}$ and $4 \mathrm{~b}[11,12]$. Among the various approaches for molecular typing of L. monocytogenes, Pulsed Field Gel Electrophoresis (PFGE) has been considered the "gold standard" owing to its high reproducibility and discriminatory ability [13]. However, Repetitive Element Sequence (REP) and Enterobacterial Repetitive Intergenic Consensus (ERIC) - PCR are relatively simple, cost-effective and discriminatory to the type genus Listeria which generate DNA fingerprint comparable to PFGE that permits discrimination within a single bacterial species $[12,14]$.

L. monocytogenes common to different environments including the agroecosystem, may serve as the contamination source. Since the first report of human listeriosis outbreak in 1980 through consumption of contaminated 
food [15], several such cases have been reported following the consumption of raw and cooked meat, dairy products and ready-to-eat foods, and raw and smoked seafood [16]. Todd and Notermans, [17] and Swaminathan and Gerner-Smidt [18] reported outbreaks of foodborne listeriosis across the various countries. The listeriosis incidence varies from 0.3 to 11.3 per million population in different countries, although no such outbreaks have been reported from India [19]. The incidence of listeriosis has also been attributed to consumption of salad vegetables such as cabbage, celery, lettuce, cucumber, onion, leeks, watercress, radish, tomatoes, and fennel $[20,21]$. Since the majority of such studies used vegetable samples randomly collected from the market, it is difficult to account for the actual inoculum source.

India is the second largest global producer of the fruits (45.5 million tones/y) and vegetables (90.8 million tones/y), contributing $10.23 \%$ and $14.45 \%$ of the total world production, respectively [22]. Therefore, it is essential to continuously monitor the prevalence of foodborne pathogens including L. monocytogenes. A few Indian reports available, show prevalence of L. monocytogenes in different vegetable and soil samples, but these are limited to the virulence attributes, antibiotics sensitivity and subtyping of the isolates [23-25]. The organism poses serious problem to the food industry, public health agencies, and government bodies $[9,26]$. In the present study, we characterized L. monocytogenes isolated from the vegetables and the respective rhizosphere soils (soil adhering to the root surface) for the presence of virulence genes, serovar and antibiotics susceptibility. For generation of DNA fingerprints and to know-how of the clonal relationships among the isolates, ERIC- and REP-PCR approach was used.

\section{Results and discussion}

\section{Prevalence of $L$. monocytogenes}

The overall prevalence of L. monocytogenes in 200 vegetable samples was 20 (10\%) and 10 (5\%) for 200 soil samples. Of the 10 vegetables, 6 of these i.e., brinjal, cauliflower, dolichos-bean, tomato, chappan-kaddu and chilli and their respective rhizospheric soils tested + ve for L. monocytogenes. Conversely, cabbage, broccoli, palak and cowpea and their respective soils tested - ve.

Reports elsewhere in other countries indicated variable prevalence of $L$. monocytogenes in vegetables. It was low $(0.62 \%)$ in North China, 3.1\% in Brazil and high (60\%) in US [26-28]. The findings of the present study on the prevalence of $L$. monocytogenes in vegetable samples, are in agreement with the values (10\% and 11\%) from the freshly supermarket prepared, cooked or raw ready-toeat vegetable-salads from Santiago, Chile and Japanese light pickle made from vegetables in Obihiro, respectively [20,29]. Studies conducted on vegetable samples in
Mumbai and Tamilnadu in India reported an average $13 \%$ prevalence of L. monocytogenes [23,25].

Among the 10 vegetables, L. monocytogenes frequency was $20 \%$ (4 contaminated samples out of 20 analyzed) in brinjal, cauliflower, chappan-kaddu and chilly while $10 \%$ ( 2 contaminated samples out of 20 analyzed) in dolichosbeans and tomato. L. monocytogenes has previously been isolated from carrot, cabbage, tomato, cucumber, green beans, broccoli, spinach etc. [20,21,27]. In India, L. monocytogenes is reported from coriander leaves (50\%), tomato (11\%), cabbage (25\%), spinach (50\%) and Brassica oleracea (100\%) [23,25].

Further the overall prevalence of $L$. monocytogenes in the rhizospheric soil samples from agricultural farm, is in accordance with the value (5\%) as reported by Moshtaghi et al., [24] from Hisar, India and also, the L. monocytogenes prevalence (5.3\%) from soils of calf-cow operation, California, U.S. [30]. However, a higher prevalence of $L$. monocytogenes (100\% and $23 \%$ ) is reported in soils from animal farm environment in Nsukka, Nigeria and New York, U.S., respectively $[31,32]$. In soils from the respective vegetables, L. monocytogenes prevalence reached $10 \%$ (2 samples contaminated out of 20) in case of cauliflower, chappan-kaddu, chilly and dolichos-beans, while 5\% (1 sample out of 20) in the rhizospheric soil of brinjal and tomato.

In the present study, vegetables such as cabbage, broccoli, palak and cowpea and their respective rhizospheric soils tested - ve for L. monocytogenes. Although, previous studies in India and elsewhere observed the presence $L$. monocytogenes in such vegetable samples [20,25,27,33]. In the current study, the apparent variation in the association of $L$. monocytogenes with the selected vegetables or the rhizospheric soils, possibly reflects the consequences of a sort of crop- or soil- specific interaction with its pathogen. However, Garrec et al., [34] and Vivant et al., [35] observed low pathogen population in a heavily contaminated environment thus limiting its isolation or even the microbes. Although a few studies showed carrot to have anti-listerial activity, while cabbage highly inhibitory to Gram - ve microorganisms along with some suppressant effect against Gram + ve ones such as L. monocytogenes [36]. The proliferation of $L$. monocytogenes in the vegetable samples depends upon several factors and their complex interactions like intrinsic properties of the food (e.g. $\mathrm{pH}, \mathrm{NaCl}$ content, water activity, composition, associated microflora, antimicrobial constituents), extrinsic factors (e.g. temperature, gas atmosphere), the physico-chemical environment of the plant surface, epiphytic fitness, biofilm formation, and bacteria-bacteria and vegetable-bacteria interactions [36,37]. Soil is the environmental niche of $L$. monocytogenes but its composition, microbial communities and macrofauna, are the extrinsic edaphic factors that regulate the fate of L. monocytogenes in the soil. Generally, 
suppression of microflora via soil sterilization permitted better growth of $L$. monocytogenes than the competitive microflora [38]. As such, deciphering environmental drivers that impact the occurrence of L. monocytogenes in soils is extremely hard as these are interconnected, and extrinsic factors (edaphic parameters, biotic environment, etc.) affect their survival [35,38]. Therefore, understanding the condition that triggers contamination or, on conversely that limits risks of contamination, is difficult in face of the complexity of the ecology of Listeria.

\section{Antibiotics susceptibility}

L. monocytogenes isolates from vegetable and their rhizospheric soil samples were tested for their antibiotic susceptibility. Out of 20 isolates from vegetable samples, 15 were resistant to ciprofloxacin and cefoxitin, while 3 only to ciprofloxacin, and 2 to cefoxitin. Similarly, out of 10 isolates from soil samples, 5 were resistant to ciprofloxacin and cefoxitin while only 4 to cefoxitin, and only 1 resistant to ciprofloxacin. All the isolates, however, were susceptible to other antibiotics tested (Table 1).

The multidrug-resistant L. monocytogenes associated with human listeriosis, has been reported from food and environment [39]. Moreover, L. monocytogenes resistant to ampicillin, erythromycin, gentamicin, kanamycin, penicillin, streptomycin, sulphonamide, trimethoprim, tetracycline, and rifampicin has also been documented $[4,26]$. In India, Dhanashree et al., [33] reported sensitivity of $L$. monocytogenes to ampicillin, ciprofloxacin, cotrimoxazole, erythromycin, penicillin and chloramphenicol. Sharma et al., [40] and Soni et al., [41] isolated multi-drug resistant $L$. monocytogenes from human clinical samples, water and milk. The application of commonly used antibiotics in humans and veterinary, the disposal of untreated effluents in the environment, and the application of faeces or dung slurries of infected (or carrier) animals onto the agricultural land, have role(s) in the development of resistance in the pathogens $[31,42]$. There is also the possibility of the spread of multidrug-resistant bacteria through intake of uncooked food, and may have severe medical and public health implications $[5,43]$. The resistance of all the isolates from soil and vegetables to ciprofloxacin and/or cefoxitin as observed in this study, indicates the possible emergence of antibiotic resistance in L. monocytogenes. This finding is significant in context of the incidence of temporal and spatial changes in the antibiotics resistance $[26,44]$. Therefore, there is a need for the continuous surveillance of the emergence of antibiotics resistance.

\section{Species and serovar identification}

Twenty isolates from vegetable samples were + ve for internalin A ( $i n l A)$ gene indicating that all of them belonged to
L. monocytogenes, and in serotype specific multiplex PCR, all the isolates were + ve for ORF2110 and ORF2819 gene indicating that these belonged to $4 \mathrm{~b}, 4 \mathrm{~d}$ or $4 \mathrm{e}$ serogroup. Similarly, 10 isolates from the soil were also + ve for internalin A (inlA) gene, and the serotyping showed them + ve for ORF2110 and ORF2819 (Table 1).

The typing of L. monocytogenes is important in epidemiological studies due to the relationship between serotypes and food-borne listeriosis, and to identify the source of contamination and the dissemination routes. As serotypes $4 \mathrm{~d}$ and $4 \mathrm{e}$ are relatively rare in food, the isolates belonging to $4 \mathrm{~b}, 4 \mathrm{~d}$ or $4 \mathrm{e}$ serogroup may be regarded as serotype $4 \mathrm{~b}[9,45]$. The present observations thus corroborate with those of others on the isolation of serogroup 4b from vegetable samples $[27,29]$. This study also shows the high prevalence of $4 \mathrm{~b}$ serotype among the $L$. monocytogenes, that is commonly associated with human listeriosis. The high incidence of this serotype in vegetable and soils may be of serious concern from the food safety perspective view point.

\section{Virulence associated genes}

Twenty isolates of $L$. monocytogenes from vegetable and 10 from soil samples were screened for the presence of virulence genes. All the 20 isolates from vegetable tested + ve for inlA, inlC, inlJ, plcA, prfA, actA, hlyA and iap genes except 1 (VC3) that lacked plcA. Similarly, all the 10 isolates from soil were + ve for $i n l A$, inlC, inlJ, plcA, prfA, actA, hlyA and iap gene (Table 1).

$L$. monocytogenes strains vary in their virulence potential. Whereas some of the L. monocytogenes strains are naturally virulent to inflict high morbidity and mortality, others non-virulent and unable to infect the mammalian host $[46,47]$. The discrimination between pathogenic and non-pathogenic strains is imperative to assess the possible significance of this microorganism from food safety and public health aspects $[48,49]$. Several protocols developed for the assessment of L. monocytogenes virulence include in vivo bioassay and in vitro cell assay. The in vivo method has limitations because of its expensive nature, and the use of animals. The in vitro assay is hampered by the lack of desired reproducibility and the time consumed during analysis. PCR based assays for the key virulence-associated genes yield rapid and reproducible results. Few studies based on the presence of key virulence proteins and genes in the whole spectrum of $L$. monocytogenes strains have contributed to the acceptable outcome [50]. This study also demonstrates that all the $L$. monocytogenes isolates, irrespective of their source, possessed internalin $i n l C$ and $i n l J$ genes indicating ability for their cellular internalization. Majority of the isolates from vegetables and soil possessed virulence genes encoding inlA, inlC, inl, plcA, prfA, actA, hlyA and iap, indicating that these possess all the requisites of a virulent strain. 
Table 1 Source of isolation, serogroup, antibiogram, ERIC- and REP- fingerprints and virulence profiles of $L$. monocytogenes used in this study

\begin{tabular}{|c|c|c|c|c|c|c|c|c|c|c|c|c|c|c|c|}
\hline \multirow[t]{2}{*}{$\begin{array}{l}\text { Sl. } \\
\text { no. }\end{array}$} & \multirow[t]{2}{*}{ Strains } & \multirow[t]{2}{*}{ Source of isolation } & \multirow[t]{2}{*}{$\begin{array}{l}\text { Date of } \\
\text { isolation }\end{array}$} & \multirow[t]{2}{*}{ Serogroup } & \multirow[t]{2}{*}{ Antibiogram } & \multirow[t]{2}{*}{$\begin{array}{l}\text { ERIC } \\
\text { type }\end{array}$} & \multirow[t]{2}{*}{$\begin{array}{l}\text { REP } \\
\text { type }\end{array}$} & \multicolumn{8}{|c|}{$\begin{array}{l}\text { Presence of following genes determined } \\
\text { by PCR }\end{array}$} \\
\hline & & & & & & & & inlA & in/C & inlJ & plcA & prfa & actA & hlyA & iap \\
\hline 1 & VB1 & Vegetable-brinjal & 15.10 .2011 & $4 b, 4 d, 4 e$ & Cf, Fox & $X V I A$ & XIIIA & + & + & + & + & + & + & + & + \\
\hline 2 & VB2 & Vegetable-brinjal & 15.10 .2011 & $4 b, 4 d, 4 e$ & Cf, Fox & $X V I A$ & XIIIA & + & + & + & + & + & + & + & + \\
\hline 3 & VB3 & Vegetable-brinjal & 15.10 .2011 & $4 b, 4 d, 4 e$ & Cf, Fox & $X V I A$ & $X I I I A$ & + & + & + & + & + & + & + & + \\
\hline 4 & VB4 & Vegetable-brinjal & 15.10.2011 & $4 b, 4 d, 4 e$ & Cf, Fox & $X V I A$ & XIIIA & + & + & + & + & + & + & + & + \\
\hline 5 & VCF1 & Vegetable-cauliflower & 15.11 .2011 & $4 b, 4 d, 4 e$ & Cf, Fox & $X V I B$ & XIIIA & + & + & + & + & + & + & + & + \\
\hline 6 & VCF2 & Vegetable-cauliflower & 15.11.2011 & $4 b, 4 d, 4 e$ & Cf, Fox & $X V I C$ & $X I I I B$ & + & + & + & + & + & + & + & + \\
\hline 7 & VCF3 & Vegetable-cauliflower & 15.11 .2011 & $4 b, 4 d, 4 e$ & Cf, Fox & $X V I I B$ & $X \mid I B$ & + & + & + & + & + & + & + & + \\
\hline 8 & VCF4 & Vegetable-cauliflower & 15.11 .2011 & $4 b, 4 d, 4 e$ & Cf, Fox & $X V I I B$ & $X I I I B$ & + & + & + & + & + & + & + & + \\
\hline 9 & VDB1 & $\begin{array}{l}\text { Vegetable-dolichos } \\
\text { bean }\end{array}$ & 15.12 .2011 & $4 b, 4 d, 4 e$ & Cf & $\mathrm{XVIIA}$ & $X I I I B$ & + & + & + & + & + & + & + & + \\
\hline 10 & VDB2 & $\begin{array}{l}\text { Vegetable-dolichos } \\
\text { bean }\end{array}$ & 15.12 .2011 & $4 b, 4 d, 4 e$ & Cf, Fox & $X V I I A$ & $X I I I B$ & + & + & + & + & + & + & + & + \\
\hline 11 & VT1 & Vegetable-tomato & 15.01.2012 & $4 b, 4 d, 4 e$ & Cf, Fox & $X V B$ & XIVB & + & + & + & + & + & + & + & + \\
\hline 12 & $\mathrm{VT} 2$ & Vegetable-tomato & 15.01 .2012 & $4 b, 4 d, 4 e$ & Cf, Fox & XVA & XIVB & + & + & + & + & + & + & + & + \\
\hline 13 & VCK1 & $\begin{array}{l}\text { Vegetable-chappan } \\
\text { kaddu }\end{array}$ & 15.01 .2012 & $4 b, 4 d, 4 e$ & Cf, Fox & XVA & XIVC & + & + & + & + & + & + & + & + \\
\hline 14 & VCK2 & $\begin{array}{l}\text { Vegetable-chappan } \\
\text { kaddu }\end{array}$ & 15.01 .2012 & $4 b, 4 d, 4 e$ & Cf & XVC & XIVB & + & + & + & + & + & + & + & + \\
\hline 15 & VCK3 & $\begin{array}{l}\text { Vegetable-chappan } \\
\text { kaddu }\end{array}$ & 15.01 .2012 & $4 b, 4 d, 4 e$ & Cf, Fox & XIV & XIVB & + & + & + & + & + & + & + & + \\
\hline 16 & VCK4 & $\begin{array}{l}\text { Vegetable-chappan } \\
\text { kaddu }\end{array}$ & 15.01 .2012 & $4 b, 4 d, 4 e$ & Cf & XIV & XIVD & + & + & + & + & + & + & + & + \\
\hline 17 & VC1 & Vegetable-chilli & 15.02 .2012 & $4 b, 4 d, 4 e$ & Fox & $X I I I$ & XIVB & + & + & + & + & + & + & + & + \\
\hline 18 & VC2 & Vegetable-chilli & 15.02.2012 & $4 b, 4 d, 4 e$ & Cf, Fox & $X I I I$ & XIVA & + & + & + & + & + & + & + & + \\
\hline 19 & VC3 & Vegetable-chilli & 15.02.2012 & $4 b, 4 d, 4 e$ & Fox & $X I I I$ & XIVA & + & + & + & - & + & + & + & + \\
\hline 20 & VC4 & Vegetable-chilli & 15.02 .2012 & $4 b, 4 d, 4 e$ & Cf, Fox & $X I I I$ & XIVA & + & + & + & + & + & + & + & + \\
\hline 21 & S1 & Soil from brinjal field & 15.10 .2011 & $4 b, 4 d, 4 e$ & Cf, Fox & XIXA & XVA & + & + & + & + & + & + & + & + \\
\hline 22 & S2 & $\begin{array}{l}\text { Soil from cauliflower } \\
\text { field }\end{array}$ & 15.11.2011 & $4 b, 4 d, 4 e$ & Cf, Fox & XIXA & XVA & + & + & + & + & + & + & + & + \\
\hline 23 & S3 & $\begin{array}{l}\text { Soil from cauliflower } \\
\text { field }\end{array}$ & 15.11.2011 & $4 b, 4 d, 4 e$ & Fox & XIXA & XVA & + & + & + & + & + & + & + & + \\
\hline 24 & S4 & $\begin{array}{l}\text { Soil from dolichos } \\
\text { bean field }\end{array}$ & 15.12 .2011 & $4 b, 4 d, 4 e$ & Cf & $X I X B$ & XVA & + & + & + & + & + & + & + & + \\
\hline 25 & S5 & $\begin{array}{l}\text { Soil from dolichos } \\
\text { bean field }\end{array}$ & 15.12 .2011 & $4 b, 4 d, 4 e$ & Cf, Fox & $X X$ & $X V A$ & + & + & + & + & + & + & + & + \\
\hline 26 & S6 & Soil from tomato field & 15.01.2012 & $4 b, 4 d, 4 e$ & Fox & $X V I I I B$ & $X V I I I$ & + & + & + & + & + & + & + & + \\
\hline 27 & S7 & $\begin{array}{l}\text { Soil from chappan } \\
\text { kaddu field }\end{array}$ & 15.01.2012 & $4 b, 4 d, 4 e$ & Fox & $X V I I I A$ & $X V I I$ & + & + & + & + & + & + & + & + \\
\hline 28 & S8 & $\begin{array}{l}\text { Soil from chappan } \\
\text { kaddu field }\end{array}$ & 15.01.2012 & $4 b, 4 d, 4 e$ & Cf, Fox & $X V I I I A$ & $\mathrm{XVl}$ & + & + & + & + & + & + & + & + \\
\hline 29 & 59 & Soil from chilli field & 15.02.2012 & $4 b, 4 d, 4 e$ & Fox & $X V I I I C$ & $X V I I$ & + & + & + & + & + & + & + & + \\
\hline 30 & S10 & Soil from chilli field & 15.02 .2012 & $4 b, 4 d, 4 e$ & Cf, Fox & $X V I I I C$ & $X V I I$ & + & + & + & + & + & + & + & + \\
\hline
\end{tabular}

Cf: ciprofloxacin; Fox: cefoxitin.

These findings are similar to the isolation of virulent $L$. monocytogenes from vegetable and soil as reported by Chen et al., [12], Maklon et al., [29] and Sant Ana et al.,
[27]. Moreover, one of the isolates from vegetables (VC3) lacking $p l c A$ showed variation in the virulence gene profile, and this could be because of the absence of the 
respective virulence gene or the incidence of some mutations in the same gene $[43,51]$.

\section{ERIC- and REP-PCR fingerprint analysis}

The ERIC-PCR of genomic DNA from $L$. monocytogenes isolates from soil and vegetables yielded a total of 8 fingerprint profiles (profiles XIII through XIX) not described earlier, and consisted of 7 to 12 bands ranging between 350 and 5200 bases (Figure 1). While 2 of the 10 isolates from the soil, showed identical fingerprint profile, other 3 isolates had almost similar ones. Similarly, 3 isolates also yielded identical profile, and 1 isolate had closely related one. Isolates from vegetables yielded five distinct fingerprints, whereas those from chilli had identical fingerprint, few isolates from chappan-kaddu showed the closely related pattern. Although remaining isolates from chappan-kaddu showed distinct fingerprints, those from tomato had closely related fingerprint patterns. Whereas isolates from brinjal had identical fingerprint profile, those from cauliflower and dolichos- bean were characterized by distinct but closely related fingerprints. There was no relationship among the fingerprint profiles of vegetable and soil isolates.

The REP-PCR of genomic DNA from L. monocytogenes from soil and vegetables showed amplification of multiple DNA fragments (450 to 6000 base) (Figure 2). Likewise, the ERIC-profile of 6 isolates from soil revealed identical to closely related fingerprints and while the remaining isolates had related to distinct fingerprints. Whereas isolates from brinjal, cauliflower and dolichos-bean had similar to identical fingerprints, isolates from chilli, tomato or chappan-kaddu had identical but different fingerprints. No correlation in fingerprint profile between the soil and vegetable isolates was observed.

ERIC- sequences located in the extragenic regions of the bacterial genome are 124 to 127 bases long elements consisting of highly conserved central inverted repeat. REP elements containing 6 degenerate positions, are 38-bp long with a 5-bp variable loop between each side of the 


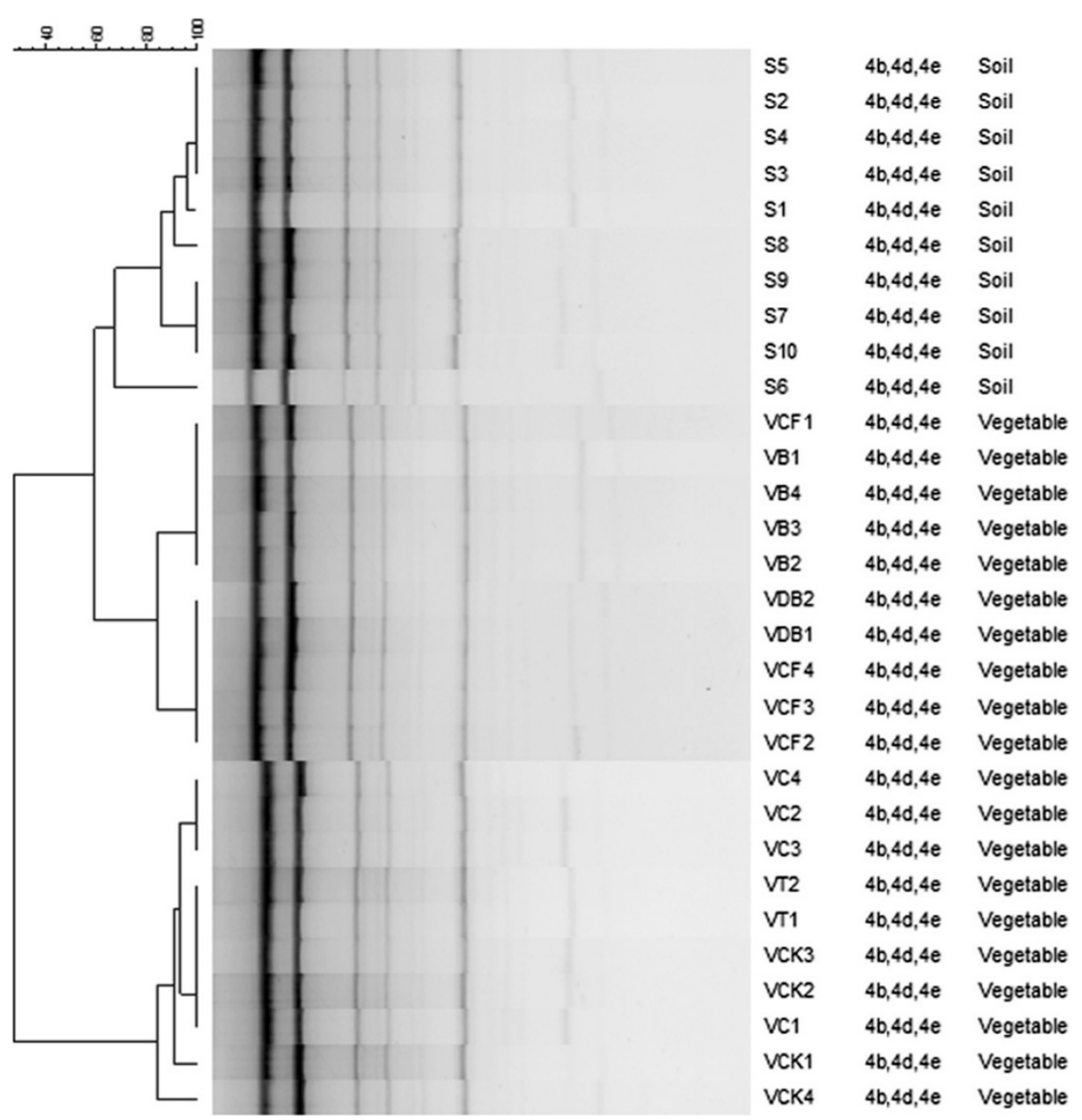

Figure 2 DNA fingerprints generated by REP-PCR amplification from vegetable and soil isolates of $L$. monocytogenes. The dendrogram was constructed using the Bionumerics Fingerprint Analyst Software (Applied Maths) as described in the legend of Figure 1.

conserved palindrome $[14,52,53]$. ERIC- and REP-PCR was used in this study to assess the relatedness of $L$. monocytogenes from the soil and vegetable, and of the serotypes. Soil isolates showed identical to similar and closely related ERIC- and REP fingerprints but distinct from the vegetable isolates indicating distinct association of strains in soils and vegetables. It is possible that many clonal types of the organism populate the soil but only distinct clones of L. monocytogenes colonize the plants. The failure to isolate strains from the roots of some plants may be due to hyperproduction of antagonists by the roots or the associated antagonist i.e., microflora. Several workers reported recovery of isolates from vegetables originating from the soil and/or the environment used for their farming $[15,21,54]$. In the overall, there is a strong correlation of the results obtained from the PCR, and the isolates from soils yielded identical fingerprint but distinct from the vegetable counterparts. The observed difference in the banding pattern among the isolates from soil and vegetables suggests the possible divergence in the genomic organization arising from the genetic re-assortment in the given ecological niche over time. There was no correlation between serogroup and the PCR fingerprint profiles.

\section{Conclusions}

In conclusion, $L$. monocytogenes isolates recovered from vegetable and soil samples belonging to $4 \mathrm{~b}, 4 \mathrm{~d}$ or $4 \mathrm{e}$ serogroups, exhibited multiple antibiotic resistances and the presence of all the virulence genes. The study provides evidence for the prevalence of pathogen i.e., L. monocytogenes in farm samples though there is no clear-cut evidence of listeriosis outbreak in India. In addition, the acquisition of antibiotic resistance in the isolates studied, reflects the potential public health consequences.

\section{Methods}

Study site and sample collection

A total of 400 samples were collected from the agricultural farm of the Indian Institute of Vegetable Research (IIVR), 
Varanasi, India $\left(25^{\circ} 08^{\prime} \mathrm{N}\right.$ latitude; $83^{\circ} 03^{\prime} \mathrm{E}$ longitude and $90 \mathrm{~m}$ from sea level), through October 2011 to February 2012, and of which, 200 each were from vegetables and the accompanying rhizospheric soils. Among the vegetables, 20 each were from brinjal (Solanum melongena), cabbage (Brassica oleracea var. capitata), broccoli (Brassica oleracea var. italica), cauliflower (Brassica oleracea var. botrytis), dolichos-bean (Dolichos lablab), palak (Beta vulgaris), tomato (Solanum lycopersicum), chappan-kaddu (Cucurbita pepo), chilli (Capsicum annum) and cowpea (Vigna unguiculata).

Rhizosphere soil (200 samples) contained 20 each from the same vegetable grown. Soil samples were collected at the ripening stage by uprooting the plants. Roots were vigorously shaken to separate the loosely bound bulk soil. Pooled soil samples from the vegetable field were homogeneously mixed and sieved $(2 \mathrm{~mm})$ to remove the plant debris prior to further analysis [55]. All the vegetable and rhizospheric soil samples were collected aseptically, transported chilled to the laboratory, and processed within $24 \mathrm{~h}$ of collection.

\section{Isolation and identification of $L$. monocytogenes}

Vegetable and soil samples were examined following the standard double enrichment method as prescribed by ISO 11290:1 with slight modifications [56]. Each vegetable sample was cut into small pieces, then $25 \mathrm{~g}$ each of vegetable and soil sample were separately placed in Stomacher bag with $225 \mathrm{ml}$ of half-Fraser broth (Difco,

Table 2 Sequences and PCR cyclic conditions of primers used for detection of selected serogroups, virulence genes and molecular typing

\begin{tabular}{|c|c|c|c|c|c|}
\hline Target gene & Primer sequence $\left(5^{\prime}-3^{\prime}\right)$ & Direction & Amplicon size(bp) & PCR cyclic conditions & References \\
\hline \multirow[t]{2}{*}{ ImoO737 } & AGG GCT TCA AGG ACT TAC CC & $\mathrm{F}$ & \multirow[t]{2}{*}{691} & \multirow{2}{*}{$\begin{array}{l}94^{\circ} \mathrm{C} \times 5^{\prime} ;\left(94^{\circ} \mathrm{C} \times 30 \mathrm{~s}, 54^{\circ} \mathrm{C} \times 75 \mathrm{~s},\right. \\
\left.72^{\circ} \mathrm{C} \times 75 \mathrm{~s}\right)_{35} ; 72^{\circ} \mathrm{C} \times 10^{\prime}\end{array}$} & \multirow[t]{2}{*}[8]{} \\
\hline & ACG ATT TCT GCT TGC CAT TC & R & & & \\
\hline \multirow[t]{2}{*}{ Imo1118 } & AGG GGT CTT AAA TCC TGG AA & $\mathrm{F}$ & \multirow[t]{2}{*}{906} & \multirow[t]{2}{*}{ Do } & \multirow[t]{2}{*}[8]{} \\
\hline & CGG CTT GTT CGG CAT ACT TA & $\mathrm{R}$ & & & \\
\hline \multirow[t]{2}{*}{ ORF2819 } & AGC AAA ATG CCA AAA CTC GT & $\mathrm{F}$ & \multirow[t]{2}{*}{471} & \multirow[t]{2}{*}{ Do } & \multirow[t]{2}{*}[8]{} \\
\hline & CAT CAC TAA AGC CTC CCA TTG & $\mathrm{R}$ & & & \\
\hline \multirow[t]{2}{*}{ ORF2110 } & AGT GGA CAA TTG ATT GGT GAA & $\mathrm{F}$ & \multirow[t]{2}{*}{597} & \multirow[t]{2}{*}{ Do } & \multirow[t]{2}{*}[8]{} \\
\hline & CAT CCA TCC CTT ACT TTG GAC & R & & & \\
\hline \multirow[t]{2}{*}{ Prs } & GCT GAA GAG ATT GCG AAA GAA G & $\mathrm{F}$ & \multirow[t]{2}{*}{370} & \multirow[t]{2}{*}{ Do } & \multirow[t]{2}{*}[8]{} \\
\hline & CAA AGA AAC CTा GGA TाT GCG G & R & & & \\
\hline \multirow[t]{2}{*}{$\operatorname{in} / A$} & ACG AGT AAC GGG ACA AAT GC & $\mathrm{F}$ & \multirow[t]{2}{*}{800} & \multirow{2}{*}{$\begin{array}{l}94^{\circ} \mathrm{C} \times 2^{\prime} ;\left(94^{\circ} \mathrm{C} \times 20 \mathrm{~s}, 55^{\circ} \mathrm{C} \times 20 \mathrm{~s},\right. \\
\left.72^{\circ} \mathrm{C} \times 50 \mathrm{~s}\right)_{30} ; 72^{\circ} \mathrm{C} \times 2^{\prime}\end{array}$} & \multirow[t]{2}{*}[7]{} \\
\hline & CCC GAC AGT GGT GCT AGA TT & $\mathrm{R}$ & & & \\
\hline \multirow[t]{2}{*}{$\mathrm{in} / \mathrm{C}$} & AAT TCC CAC AGG ACA CAA CC & $\mathrm{F}$ & \multirow[t]{2}{*}{517} & \multirow[t]{2}{*}{ Do } & \multirow[t]{2}{*}[7]{} \\
\hline & CGG GAA TGC AAT TTT TCA CTA & R & & & \\
\hline \multirow[t]{2}{*}{ inlJ } & TGT AAC CCC GCT TAC ACA GTT & $\mathrm{F}$ & \multirow[t]{2}{*}{238} & \multirow[t]{2}{*}{ Do } & {$[7]$} \\
\hline & AGC GGC TTG GCA GTC TAA TA & $\mathrm{R}$ & & & \\
\hline plcA & CTG CTT GAG CGT TCA TGT CTC ATC CCC C & $\mathrm{F}$ & 1484 & $95^{\circ} \mathrm{C} \times 2^{\prime} ;\left(95^{\circ} \mathrm{C} \times 15 \mathrm{~s}, 60^{\circ} \mathrm{C} \times 30 \mathrm{~s}\right.$, & {$[60]$} \\
\hline & CAT GGG TTT CAC TCT CCT TCT AC & $\mathrm{R}$ & & & \\
\hline prfa & CTG TTG GAG CTC TTC TTG GTG AAG CAA TCG & $\mathrm{F}$ & 1060 & Do & {$[60]$} \\
\hline & AGC AAC CTC GGT ACC ATA TAC TAA CTC & R & & & \\
\hline$a c t A$ & CGC CGC GGA AAT TAA AAA AAG A & $\mathrm{F}$ & 839 & Do & {$[61]$} \\
\hline & ACG AAG GAA CCG GGC TGC TAG & $\mathrm{R}$ & & & \\
\hline hlyA & GCA GTT GCA AGC GCT TGG AGT GAA & $\mathrm{F}$ & 456 & Do & {$[62]$} \\
\hline & GCA ACG TAT CCT CCA GAG TGA TCG & R & & & \\
\hline lap & ACA AGC TGC ACC TGT TGC AG & $\mathrm{F}$ & 131 & Do & [63] \\
\hline & TGA CAG CGT GTG TAG TAG CA & $\mathrm{R}$ & & & \\
\hline REPIR-I & IIIICGICGICATCIGGC & $\mathrm{F}$ & Several & $95^{\circ} \mathrm{C} \times 7^{\prime} ;\left(95^{\circ} \mathrm{C} \times 1^{\prime}, 44^{\circ} \mathrm{C} \times 1^{\prime}\right.$ & {$[52]$} \\
\hline REP2-I & ICGICTTATCIGGCCTAC & $\mathrm{R}$ & & & \\
\hline ERICIR & ATGTAAGCTCCTGGGGATTCAC & $\mathrm{F}$ & Several & $95^{\circ} \mathrm{C} \times 7^{\prime} ;\left(95^{\circ} \mathrm{C} \times 1^{\prime}, 52^{\circ} \mathrm{C} \times 1^{\prime}\right.$ & [64] \\
\hline ERIC2 & AAGTAAGTGACTGGGGTGAGCG & $\mathrm{R}$ & & & \\
\hline
\end{tabular}


USA), and homogenized using Stomacher (60 s). The bag was incubated $\left(24 \mathrm{~h}, 30^{\circ} \mathrm{C}\right)$. Second enrichment was done by adding $0.1 \mathrm{ml}$ from the overnight grown culture into $10 \mathrm{ml}$ of the full strength of the selective agents (Fraser broth, Difco, USA), and incubated $\left(48 \mathrm{~h}, 37^{\circ} \mathrm{C}\right)$ with the subsequent spreading on PALCAM agar (Difco), and re-incubated $\left(48 \mathrm{~h}, 37^{\circ} \mathrm{C}\right)$. Grey-greenish colonies with black sunken centre and black halo were picked up and confirmed by Gram staining, biochemical tests such as catalase, methyl red-Voges-Proskauer (MR-VP) reaction, nitrate reduction, motility $\left(20-25^{\circ} \mathrm{C}\right)$, acid production from rhamnose, xylose, mannitol, $\alpha$-methyl-D-mannopyranoside, and CAMP test with Staphylococcus aureus and Rhodococcus equi [57]. L. monocytogenes MTCC1143, S. aureus MTCC1144 and R. equi MTCC1135 served as control. All the L. monocytogenes isolates and control strains were preserved in tryptic soy agar slants at room temperature for use in the subsequent analysis.

\section{Antibiotics susceptibility test}

All L. monocytogenes isolates were tested for their susceptibility to 10 antibiotics commonly used in veterinary and human therapy, using the disc diffusion method of Bauer et al., [58]. Antibiotics discs (Oxoid, UK) with the following concentrations were used: ampicillin (A, $10 \mu \mathrm{g})$, chloramphenicol (C, $30 \mu \mathrm{g})$, ciprofloxacin (Cf, $5 \mu \mathrm{g}$ ), cefoxitin (Fox, $30 \mu \mathrm{g}$ ), co-trimoxazole (SXT, $25 \mu \mathrm{g}$ ), gentamicin (G, $10 \mu \mathrm{g})$, oflaxacin (Of, $5 \mu \mathrm{g})$, rifampicin (R, $5 \mu \mathrm{g}$ ), streptomycin $(\mathrm{S}, 10 \mu \mathrm{g})$, and tetracycline $(\mathrm{T}, 30 \mu \mathrm{g})$. The diameter of the clearance zone was recorded and interpreted following the guidelines of the Clinical and Laboratory Standards Institute (CLSI) for Gram + ve bacteria [59].

\section{DNA isolation}

Chromosomal DNA was extracted from L. monocytogenes isolates grown overnight $\left(37^{\circ} \mathrm{C}\right)$ with shaking (200 oscillations per min) in brain heart infusion broth (BHIB, Difco, USA) following the protocol of QIAGEN DNeasy ${ }^{\circ}$ Blood \& Tissue kit. Harvested biomass (maximum $2 \times 10^{9}$ cells) were centrifuged (7500 rpm, $10 \mathrm{~min}$ ), re-suspended in $180 \mu \mathrm{l}$ lysis buffer [20 mM Tris-Cl (pH 8.0), $2 \mathrm{mM}$ NaEDTA, 1.2\% Triton $^{\ominus} \mathrm{X}-100,20 \mathrm{mg}$ lysozyme (Sigma) per $\mathrm{ml}$ ], and incubated for $30 \mathrm{~min}\left(37^{\circ} \mathrm{C}\right)$. Proteinase $\mathrm{K}$ $(25 \mu \mathrm{l})$ and $200 \mu \mathrm{l}$ Buffer AL (without ethanol) were added, mixed by vortexing and the mixture re-incubated at $56^{\circ} \mathrm{C}(30 \mathrm{~min})$. Thereafter, $4 \mu \mathrm{l}$ RNase $\mathrm{A}(100 \mathrm{mg} / \mathrm{ml})$ was added and incubated (2 $\mathrm{min})$ at room temperature. Pure ethanol $(200 \mu \mathrm{l})$ was added to the sample, and mixed by vortexing. The DNA was eluted in AE Buffer, and the concentration and purity determined with the help of Eppendorf spectrophotometer at 260 and $280 \mathrm{~nm}$, respectively.

\section{Species- and virulence- specific genes and serogroup identification}

The presence of internalin genes (inlA, inlC and inlJ), virulence-associated genes (plcA, actA, hlyA, iap and prfA) and serogroup (1/2a, $1 / 2 \mathrm{~b}, 1 / 2 \mathrm{c}$, and $4 \mathrm{~b})$ was determined by multiplex PCR as described by Liu et al., [7], Notermans et al., [60] and Doumith et al., [8], respectively, and subsequently modified by Soni et al., [41]. The PCR products were analyzed by agarose (1.5\%) gel electrophoresis, stained with ethidium bromide, and visualized under UV transilluminator (Bio-Rad). The details of oligonucleotide sequences (Sigma) and PCR cyclic conditions used in this study, are given in Table 2.

\section{Genomic fingerprinting by ERIC- and REP-PCR}

ERIC- and REP- PCR were performed as described by Rivera et al., [52] and Versalovic et al., [64], respectively. The amplicons were electrophoresed on $1.8 \%$ agarose at $60 \mathrm{~V}(6 \mathrm{~h})$, stained with ethidium bromide and analyzed as described [41]. The fingerprint pattern was measured in a Fluoro-S-Imager (Bio-Rad) and analyzed using Bionumerics fingerprint analyst (Applied Maths, Kortrejik, Belgium) software with a simple-matching similarity matrix, and the data were clustered by the un-weighted pair group method with arithmetic means (UPGMA). The clustering analysis of the ERIC- and REP-PCR patterns could be affected by factors like position bias in gels, band assignment, and different settings in the BioNumerics software. Therefore, the similarity of the ERIC- and REP-PCR fingerprint profiles was calculated using the average simple-match similarity matrix and the default cluster settings of $0 \%$ optimization and $1 \%$ band position tolerance.

Competing interests

The authors declare that they have no competing interests.

\section{Authors' contributions}

DKS and SKD contributed to design the experiment, data analysis and ms preparation. DVS contributed to REP and ERIC analysis. MS contributed to providing sampling sites and samplings. All the authors have read and approved the final draft before submission to BMC Microbiology.

\section{Acknowledgements}

The study was supported by Indian Council of Medical Research, New Delhi grant No. 5/3/3/10/2007-ECD-I to SKD, and fund contributed by the Department of Biotechnology, New Delhi to Institute of Life Sciences, Bhubaneswar. Authors thank Ms. Sasmita Panda for her support in ERIC and REP data.

\section{Author details}

${ }^{1}$ Department of Botany, Banaras Hindu University, Varanasi 221005, India. ${ }^{2}$ Indian Institute of Vegetable Research, Varanasi 221305, India. ${ }^{3}$ Infectious Disease Biology, Institute of Life Sciences, Bhubaneswar 751023, India.

Received: 13 March 2014 Accepted: 2 September 2014

Published online: 08 September 2014

\section{References}

1. Roussel S, Félix B, Grant K, Dao TT, Brisabois A, Amar C: Fluorescence amplified fragment length polymorphism compared to pulsed field gel electrophoresis for Listeria monocytogenes subtyping. BMC Microbiol 2013, 13:14. 
2. $[\mathrm{WHO}]$ World Health Organization and Food and Agricultural Organization: Risk assessment of Listeria monocytogenes in ready-to-eat foods. In , Volume 4-5. Rome Italy: MRA; 2004.

3. Kyoui D, Takahashi H, Miya S, Kuda T, Kimura B: Comparison of the major virulence-related genes of Listeria monocytogenes in internalin A truncated strain 36-25-1 and a clinical wild-type strain. BMC Microbiol 2014, 14:15.

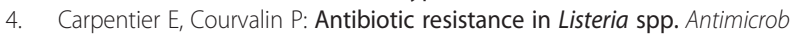
Agents Chemother 1999, 43:2103-2108.

5. Nwachukwu NC, Orji FA, Iheukwumere I, Ekeleme UG: Antibiotic resistant environmental isolates of Listeria monocytogenes from anthropogenic lakes in Lokpa-Ukwu, Abia State of Nigeria. Aust J Basic App/ Sci 2010, 4:1571-1576.

6. Vazquez-Boland JA, Kuhn M, Berche P, Chakraborty T, Dominguez-Bernal G, Goebel W, Gonzalez-Zorn B, Wehland J, Kreft J: Listeria pathogenesis and molecular virulence determinants. Clin Microbiol Rev 2001, 14:584-640.

7. Liu D, Lawrence ML, Austin FW, Ainsworth AJ: A multiplex PCR for species- and virulence-specific determination of Listeria monocytogenes. J Microbiol Methods 2007, 71:133-140.

8. Doumith M, Buchriester C, Glaser P, Jacquet C, Martin P: Differentiation of the major Listeria monocytogenes serovars by multiplex PCR. J Clin Microbiol 2004, 42:3819-3822.

9. Liu D: Identification, subtyping and virulence determination of Listeria monocytogenes, an important foodborne pathogen. J Med Microbiol 2006, 55:645-659.

10. Wang $Y$, Zhao A, Zhu R, Lan R, Jin D, Cui Z, Wang Y, Li Z, Wang Y, Xu J, Ye C: Genetic diversity and molecular typing of Listeria monocytogenes in China. BMC Microbiol 2012, 12:119.

11. Farber JM, Peterkin PI: Listeria monocytogenes, a food borne pathogen. Clin Microbiol Rev 1991, 55:476-511.

12. Chen B, Pyla R, Kim T, Silva JL, Jung Y: Prevalence and contamination patterns of Listeria monocytogenes in catfish processing environment and fresh fillets. Food Microbiol 2010, 27:645-652.

13. Gerner-Smidt P, Hise K, Kincaid J, Hunter S, Rolando S, Hyytia-Trees E, Ribot EM, Swaminathan B: PulseNet USA: a five-year update. Foodborne Pathog Dis 2006, 3:9-19.

14. Jersek B, Gilot P, Gubina M, Klun N, Mehle J, Teherneva E, Rijpens N, Herman L: Typing of Listeria monocytogenes strains by repetitive element sequence-based PCR. J Clin Microbiol 1999, 37:103-109.

15. Schlech WF III, Lavigne PM, Bortolussi RA, Allen AC, Haldane EV, Wort AJ, Hightower AW, Johnson SE, King SH, Nicholls ES, Broome CV: Epidemic listeriosis-evidence for transmission by food. N Eng J Med 1983, 308:203-206.

16. $[C D C]$ Centre for Disease Control and Prevention: Investigation update: multistate outbreak of listeriosis linked to whole cantaloupes from Jensen Farms, Colorado. 2011, http://www.cdc.gov/listeria/outbreaks/ cantaloupes-jensen-farms/index.html?s_cid=cs_654.

17. Todd ECD, Notermans S: Surveillance of listeriosis and its causative pathogen, Listeria monocytogenes. Food Control 2011, 22:1484-1490.

18. Swaminathan B, Gerner-Smidt P: The epidemiology of human listeriosis. Microbes Infect 2007, 9:1236-1243.

19. Barbuddhe SB, Malik SVS, Kumar JA, Kalorey DR, Chakraborty T: Epidemiology and risk management of listeriosis in India. Int J Food Microbiol 2012, 154:113-118.

20. Cordano AM, Jacquet C: Listeria monocytogenes isolated from vegetable salads sold at supermarkets in Santiago, Chile: prevalence and strain characterization. Int J Food Microbiol 2009, 132:176-179.

21. Ponniah J, Robin T, Paie MS, Radu S, Ghazali FM, Kqueen CY, Nishibuchi M, Nakaguchi Y, Malakar PK: Listeria monocytogenes in raw salad vegetables sold at retail level in Malaysia. Food Control 2010, 21:774-778.

22. [NHB] National Horticulture Board: 2013. http://nhb.gov.in/ commodity_bulletin.html.

23. Pingulkar K, Kamat A, Bongirwar D: Microbiological quality of fresh leafy vegetables, salad components and ready-to-eat salads: an evidence of inhibition of Listeria monocytogenes in tomatoes. Int J Food Sci Nutr 2001, 52:15-23.

24. Moshtaghi H, Garg SR, Mandokhot UV: Prevalence of Listeria in soil. Indian J Exp Biol 2003, 41:1466-1468.

25. Shrinithivihashini ND, Sheelamary M, Mahamuni D, Chithradevi R: Occurrence of Listeria monocytogenes in food and ready to eat food products available in Tiruchirappalli, Tamil Nadu, India. World J Life Sci Med Res 2011, 1:70-75.
26. Yan H, Neogi SB, Mo Z, Guan W, Shen Z, Zhang S, Li L, Yamasaki S, Shi L, Zhong N: Prevalence and characterization of antimicrobial resistance of foodborne Listeria monocytogenes isolates in Hebei province of Northern China, 2005-2007. Int J Food Microbiol 2010, 144:310-316.

27. Sant Ana AS, Igarashi MC, Landgraf M, Destro MT, Franco BDGM: Prevalence, populations and pheno- and genotypic characteristics of Listeria monocytogenes isolated from ready-to-eat vegetables marketed in São Paulo, Brazil. Int J Food Microbiol 2012, 155:1-9.

28. Beuchat LR, Berrang ME, Brackett RE: Presence and public health implications of Listeria monocytogenes on vegetables. In Foodborne Listeriosis. Edited by Miller AL, Smith JL, Somkuti GA. 1990:175-181.

29. Maklon K, Minami A, Kusumoto A, Takeshi K, Thuy NTB, Makino S, Kawamoto K: Isolation and characterization of Listeria monocytogenes from commercial asazuke (Japanese light pickles). Int J Food Microbio/ 2010, 139:134-139.

30. Mohammed HO, Atwill E, Dunbar L, Ward T, McDonough P, Gonzalez R, Stipetic K: The risk of Listeria monocytogenes infection in beef cattle operations. J Appl Microbiol 2010, 108:349-356.

31. Nightingale KK, Schukken $Y H$, Nightingale CR, Fortes ED, Ho AJ, Her Z, Grohn YT, McDonough PL, Wiedmann M: Ecology and transmission of Listeria monocytogenes infecting ruminants and in farm environment. Appl Environ Microbiol 2004, 70:4458-4467.

32. Ikeh MAC, Obi SKC, Ezeasor DN, Ezeonu IM, Moneke AN: Incidence and pathogenicity profile of Listeria sp. isolated from food and environmental samples in Nsukka, Nigeria. Afr J Biotechnol 2010, 9:4776-4782.

33. Dhanashree B, Otta SK, Karunasagar I, Goebel W, Karunasagar I: Incidence of Listeria spp. in clinical and food samples in Mangalore, India. Food Microbiol 2003, 20:447-453.

34. Garrec N, Picard-Bonnaud F, Pourcher AM: Occurrence of Listeria sp. and L. monocytogenes in sewage sludge used for land application: effect of dewatering, liming and storage in tank on survival of Listeria species. FEMS Immunol Med Microbiol 2003, 35:275-283.

35. Vivant A, Garmyn D, Piveteau P: Listeria monocytogenes, a down-to-earth pathogen. Front Cell Infect Microbiol 2013, 3:87.

36. Sant Ana AS, Barbosa MS, Destro MT, Landgraf M, Franco BDGM: Growth potential of Salmonella spp. and Listeria monocytogenes in nine types of ready-to-eat vegetables stored at variable temperature conditions during shelf-life. Int J Food Microbiol 2012, 157:52-58.

37. Skalina L, Nikolajeva V: Growth potential of Listeria monocytogenes strains in mixed ready-to-eat salads. Int J Food Microbiol 2010, 144:317-321.

38. Locatelli A, Spor A, Jolivet C, Piveteau P, Hartmann A: Biotic and abiotic soil properties influences survival of Listeria monocytogenes in soil. PLoS One 2013, 8:e75969.

39. Carpentier E, Gerbaud G, Jacquet C, Rocourt J, Courvalin P: Incidence of antibiotic resistance in Listeria species. J Infect Dis 1995, 172:277-281.

40. Sharma D, Sharma PK, Saharan BS, Malik A: Isolation, identification and antibiotic susceptibility profiling of antimicrobial resistant Listeria monocytogenes from dairy milk. Int J Microb Resour Technol 2012, 1:1-4

41. Soni DK, Singh RK, Singh DV, Dubey SK: Characterization of Listeria monocytogenes isolated from Ganges water, human clinical and milk samples at Varanasi, India. Infect Genet Evol 2013, 14:83-91.

42. Chukwu OOC, Ogbonna CIC, Olabode OA, Chukwu DI, Owuliri FC, Nwankiti OO: Listeria monocytogenes in Nigerian processed meats and ready to eat dairy products. Niger J Microbiol 2006, 20:900-904.

43. Rodas-Suarez OR, Flores-Pedroche JF, Betancourt-Rule JM, Quinones-Ramirez EI, Vazquez-Salinas C: Occurrence and antibiotic sensitivity of Listeria monocytogenes strains isolated from oysters, fish and estuarine water. Appl Environ Microbiol 2006, 72:7410-7412.

44. Lyon SA, Berrang ME, Fedorka-Cray PJ, Fletcher DL, Meinersmann RJ: Antimicrobial resistance of Listeria monocytogenes isolated from a poultry further processing plant. Foodborne Path Dis 2008, 5:253-259.

45. Aurora R, Prakash A, Prakash S: Genotypic charaterization of Listeria monocytogenes isolated from milk and ready-to-eat indigenous milk products. Food Control 2009, 20:835-839.

46. Liu D, Ainsworth AJ, Austin FW, Lawrence ML: Characterization of virulent and avirulent Listeria monocytogenes strains by PCR amplification of putative transcriptional regulator and internalin genes. J Med Microbiol 2003, 52:1066-1070.

47. Velge $\mathrm{P}$, Roche SM: Variability of Listeria monocytogenes virulence: a result of the evolution between saprophytism and virulence? Future Microbiol 2010, 5:1799-1821. 
48. Jensen A, Thomsen LE, Jørgensen RL, Larsen MH, Roldgaard BB, Christensen BB, Vogel BF, Gram L, Ingmer H: Processing plant persistent strains of Listeria monocytogenes appear to have a lower virulence potential than clinical strains in selected virulence models. Int J Food Microbiol 2008, 123:254-261.

49. Roberts AJ, Williams SK, Wiedmann M, Nightingale KK: Some Listeria monocytogenes outbreak strains demonstrate significantly reduced invasion, inlA transcript levels, and swarming motility in vitro. App/ Environ Microbiol 2009, 75:5647-5658.

50. Jaradat ZW, Schutze GE, Bhunia AK: Genetic homogeneity among Listeria monocytogenes strains from infected patients and meat products from two geographic locations determined by phenotyping, ribotyping and PCR analysis of virulence genes. Int J Food Microbiol 2002, 76:1-10.

51. Kalorey DR, Warke SR, Kurkure NV, Rawool DB, Barbuddhe SB: Listeria species in bovine raw milk: a large survey of Central India. Food Control 2008, 19:109-112.

52. Rivera IG, Chowdhury MAR, Huq A, Jacobs D, Martins MT, Colwell RR: Enterobacterial repetitive intergenic consensus sequences and the PCR to generate fingerprints of genomic DNA from Vibrio cholerae 01, 0139 and non-O1 strains. Appl Environ Microbiol 1995, 61:2898-2904.

53. Fugett EB, Schoonmaker-Bopp D, Dumas NB, Corby J, Wiedmann M: Pulsed field gel electrophoresis (PFGE) analysis of temporally matched Listeria monocytogenes isolated from human, clinical cases, food, ruminant farms, and urban and natural environments reveals source associated as well as widely distributed PFGE types. J Clin Microbiol 2007, 45:865-873.

54. Heisick JE, Wagner DE, Nierman ML, Peeler JT: Listeria spp. found on fresh market produce. Appl Environ Microbiol 1989, 55:1925-1927.

55. Singh AK, Singh M, Dubey SK: Changes in Actinomycetes community structure under the influence of $B t$ transgenic brinjal crop in a tropical agroecosystem. BMC Microbiol 2013, 13:122.

56. Anonymous: EN ISO 11290-1 Microbiology of food and animal feeding stuffs - horizontal method for the detection and enumeration of Listeria monocytogenes - part 1: detection. In Geneva: International Organization for Standardisation; 1997.

57. Seeliger HPR, Jones D: Listeria. In Bergey's manual of systematic bacteriology. 9th edition. Edited by Sneath PHA, Maine NS, Sharpe ME, Holt JG. Baltimore, Maryland: Williams and Wilkins; 1986:1235-1245.

58. Bauer AW, Kirby WM, Sherris JC, Turck M: Antibiotic susceptibility testing by a standardized single disk method. Am J Clin Pathol 1966, 45:493-496

59. [CLSI] Clinical and Laboratory Standards Institute: Performance standards for antimicrobial disk susceptibility tests; approved standard-ninth edition (M2-A9). In Wayne, Pa: Clinical and Laboratory Standards Institute; 2006.

60. Notermans SH, Dufrenne J, Leimeister-Wachter M, Domann E, Chakraborty T: Phosphatidylinositol-specific phospholipase $C$ activity as a marker to distinguish between pathogenic and non-pathogenic Listeria species. Appl Envrion Microbiol 1991, 57:2666-2670.

61. Suarez M, Gonzalez-Zorn B, Vega Y, Chico-Calero I, Vazquez-Boland JA: A role for act $A$ in epithelial cell invasion by Listeria monocytogenes. Cell Microbiol 2001, 3:853-864.

62. Paziak-Domanska B, Bogulawska E, Wiekowska-Szakiel M, Kotlowski R, Rozalska B, Chmiela M, Kur J, Dabrowski W, Rudnicka W: Evaluation of the API test, phosphatidylinositol- specific phospholipase $C$ activity and PCR method in identification of Listeria monocytogenes in meat foods. FEMS Microbiol Lett 1999, 171:209-214.

63. Furrer B, Candrian U, Hoefelein C, Luethy J: Detection and identification of Listeria monocytogenes in cooked sausage products and in milk by in vitro amplification of haemolysin gene fragments. J Appl Bacteriol 1991, 70:372-379

64. Versalovic JT, Koeuth T, Lupski JR: Distribution of repetitive DNA sequences in Eubacteria and application to fingerprinting of bacterial genomes. Nucleic Acids Res 1991, 19:6823-6831.

doi:10.1186/s12866-014-0241-3

Cite this article as: Soni et al:: Virulence and genotypic characterization of Listeria monocytogenes isolated from vegetable and soil samples. BMC Microbiology 2014 14:241.

\section{Submit your next manuscript to BioMed Central and take full advantage of:}

- Convenient online submission

- Thorough peer review

- No space constraints or color figure charges

- Immediate publication on acceptance

- Inclusion in PubMed, CAS, Scopus and Google Scholar

- Research which is freely available for redistribution

Submit your manuscript at www.biomedcentral.com/submit
C Biomed Central 